\title{
Utajony zespół Brugadów - sukces czy porażka? Odpowiedzi dostarczy wszczepialny rejestrator zdarzeń
}

\author{
Latent Brugada syndrome - success or failure? \\ Implantable loop recorder will provide the answer \\ Maciej Nadel, Paweł Ptaszyński, Krzysztof Kaczmarek, \\ Jerzy Krzysztof Wranicz, Iwona Cygankiewicz \\ Klinika Elektrokardiologii Uniwersytetu Medycznego w Łodzi
}

\section{Streszczenie}

Pacjent w wieku 29 lat został przyjęty do szpitala z powodu 2 epizodów zasłabnięć oraz pełnej utraty przytomności. W wywiadzie, badaniu przedmiotowym oraz badaniach dodatkowych nie stwierdzono odchyleń od normy. W elektrokardiogramie (EKG) spoczynkowym zaobserwowano zmiany sugerujące podejrzenie zespołu Brugadów typu 2. Po wykonaniu próby prowokacyjnej z zastosowaniem ajmaliny zapis EKG wykazał cechy zespołu Brugadów typu 1. Ze względu na niskie ryzyko nagłego zgonu sercowego oraz niejasny mechanizm omdleń pacjenta nie kwalifikowano do implantacji kardiowertera-defibrylatora. Zdecydowano o wszczepieniu rejestratora zdarzeń w celu weryfikacji arytmicznej etiologii omdleń.

Słowa kluczowe: zespół Brugadów, nagły zgon sercowy, kardiowerter-defibrylator, wszczepialny rejestrator zdarzeń

Folia Cardiologica 2015; 10, supl. C: 10-12

\section{Opis przypadku}

Pacjent w wieku 29 lat został przyjęty do szpitala wojewódzkiego z powodu 2 epizodów zasłabnięć oraz jednej pełnej utraty przytomności w ciągu miesiąca poprzedzającego hospitalizację. Incydenty nie były poprzedzone kołataniami serca; ich okoliczności nie sugerowały tła arytmicznego, a raczej charakter wazowagalny. Pacjent nie zgłaszał objawów sugerujących choroby układu krążenia. W badaniu przedmiotowym nie stwierdzono odchyleń od normy. Wywiad w kierunku nagłego zgonu sercowego w rodzinie był negatywny. Badania dodatkowe w kierunku neurologicznych i arytmogennych przyczyn omdleń (m.in. badanie elektroencefalograficzne, tomografia komputerowa głowy, elektrokardiografia [EKG] spoczynkowa, próba wysiłkowa, badanie echokardiograficzne oraz 24-godz. EKG metodą
Holtera) nie pozwoliły na ustalenie prawdopodobnej przyczyny zgłaszanych dolegliwości. Pacjent został skierowany do Kliniki Elektrokardiologii Uniwersytetu Medycznego w Łodzi w celu przeprowadzenia dalszej diagnostyki.

W spoczynkowym zapisie EKG obserwowano zmiany nasuwające podejrzenie zespołu Brugadów typu 2 (ryc. 1). Zdecydowano o przeprowadzeniu u chorego próby z podaniem ajmaliny w dawce $1 \mathrm{mg} / \mathrm{kg}$ mc. w 10-minutowym wlewie dożylnym. Przed wykonaniem badania elektrody EKG przyklejono w zmodyfikowanym położeniu (ryc. 2). W EKG przedstawionym na rycinie 3 odprowadzenia oznaczone jako V5 i V6 odpowiadają położeniu V1 i V2 o dwa międzyżebrza wyżej. W trakcie dożylnego wlewu ajmaliny obserwowano stopniową indukcję elektrokardiograficznych cech zespołu Brugadów typu 1 (ryc. 4). Po zakończeniu dożylnego wlewu ajmaliny stwierdzono stopniowe wycofywanie

Adres do korespondencji: lek. Maciej Nadel, Klinika Elektrokardiologii, Uniwersytet Medyczny w Łodzi, Centrum Kliniczno-Dydaktyczne,

ul. Pomorska 251, 92-213 Łódź, tel./faks 484220143 60/361, e-mail: maciejnadel@gmail.com 


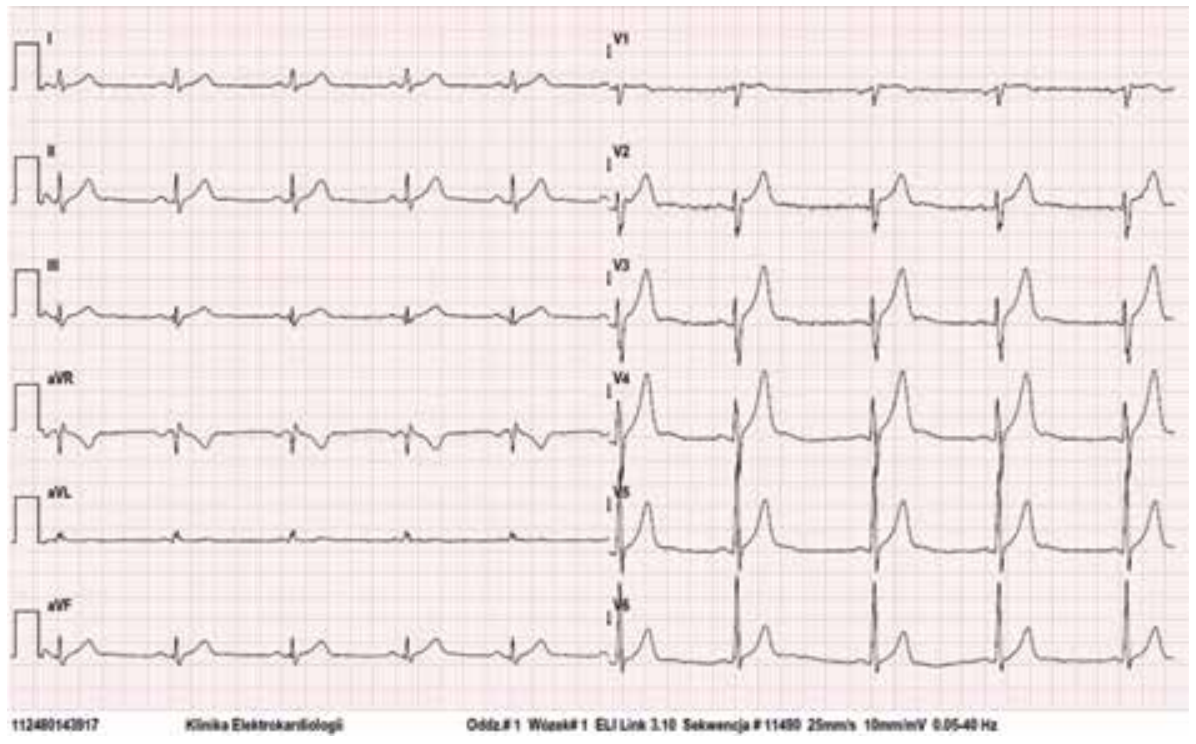

Rycina 1. Zmiany nasuwające podejrzenie zespołu Brugadów typu 2

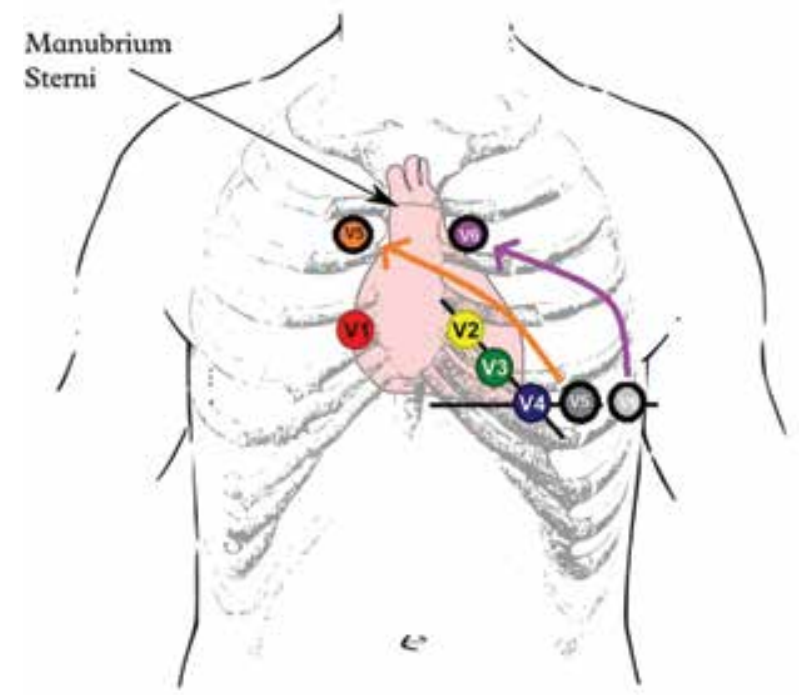

Rycina 2. Modyfikacja położenia elektrod przez kolejnym badaniem elektrokardiograficznym; manubrium sterni (łac.) - rękojeść mostka

się cech zespołu Brugadów typu 1, z pełnym powrotem do stanu wyjściowego po kilkunastu minutach.

Ze względu na wywiad omdleń o charakterze wazowagalnym wykonano test pochyleniowy (wynik negatywny). W badaniu elektrofizjologicznym, zarówno w stanie podstawowym, jak i po podaniu leków, żadną ze stosowanych stymulacji nie wyzwolono arytmii komorowej.

Zespół Brugadów wiąże się ze zwiększonym ryzykiem wystąpienia nagłego zgonu sercowego [1]. Spośród kryteriów elektrokardiograficznych jedynie typ 1 jest diag-

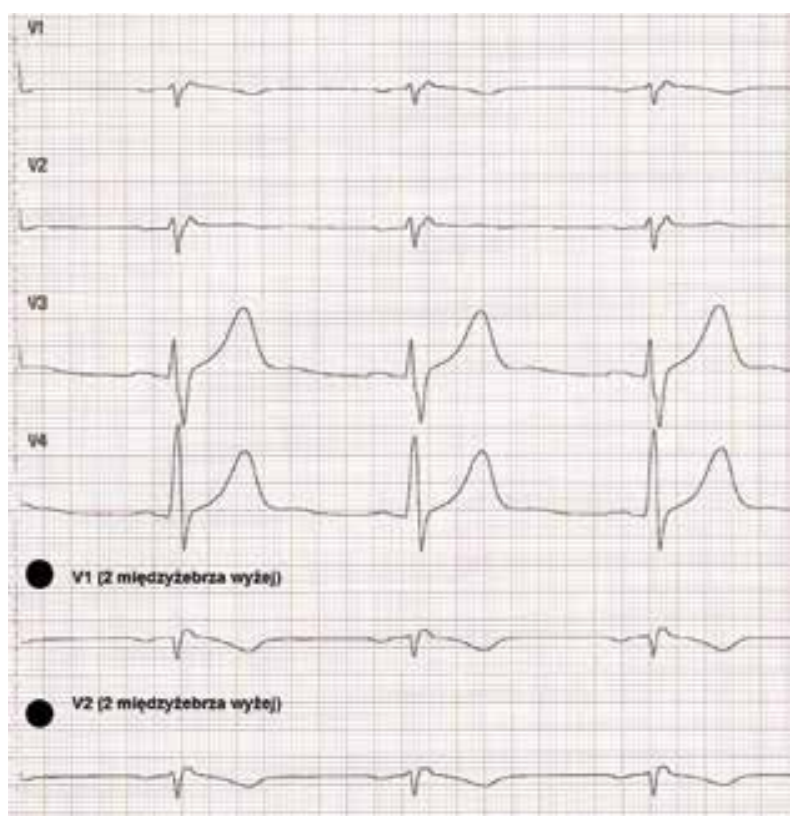

Rycina 3. Odprowadzenia V5 i V6 odpowiadające położeniom V1 i V2 o dwa międzyżebrza wyżej w porównaniu z ryciną 1

nostyczny dla zespołu Brugadów [2]. Omawiany pacjent w zapisie spoczynkowym wykazywał cechy EKG sugerujące zespół Brugadów typu 2. Tego typu zapis może cechować zmienność w czasie, co powoduje, że zmienia się typ zapisu lub całkowicie traci on cechy charakterystyczne [3]. Wykonanie próby z podaniem blokera kanału sodowego (np. ajmaliny) pozwala na uwidocznienie ewentualnych ukrytych cech charakterystycznych dla zespołu Brugadów typu 1 [4]. Dowiedziono jednak, że pojawienie się cech 


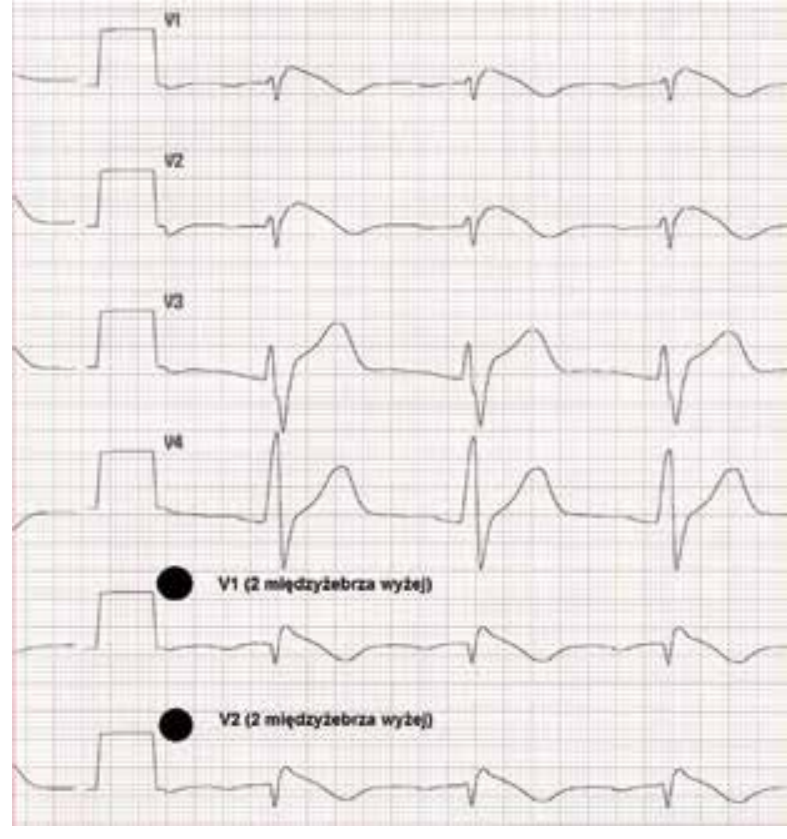

Rycina 4. Stopniową indukcja elektrokardiograficznych cech zespołu Brugadów typu 1 w wyniku dożylnego wlewu ajmaliny

zespołu Brugadów typu 1 dopiero po podaniu blokera kanału sodowego jest związane z niższym ryzykiem nagłego zgonu sercowego niż w przypadku spoczynkowego typu $1[5,6]$. W obecnie obowiązujących wytycznych [2] podkreśla się, że istotną rolę prognostyczną w kontekście kwalifikacji do wszczepienia kardiowertera-defibrylatora (ICD, implantable cardioverter-defibrillator) pacjenta z zespołem Brugadów odgrywają jedynie omdlenia o charakterze arytmicznym. U opisywanego chorego wywiad sugerował tło wazowagalne. Brak groźnych zaburzeń rytmu w ambulatoryjnym badaniu EKG oraz brak możliwości indukcji tachyarytmii w badaniu elektrofizjologicznym były kolejnymi czynnikami przemawiającymi przeciw implantacji urządzenia [2]. Implantacja wszczepialnego rejestratora zdarzeń (ILR, implantable loop recorder) jest jedną z metod pozwalających na wykrycie arytmicznej przyczyny omdleń i rejestrację możliwych groźnych tachyarytmii.

\section{Podsumowanie}

Wobec całości obrazu klinicznego - wywiad omdleń, prawdopodobnie o charakterze wazowagalnym, brak arytmii w spoczynku, w trakcie próby wysiłkowej oraz w trakcie badania elektrofizjologicznego, negatywny wywiad rodzinny - pacjenta nie kwalifikowano do wszczepienia ICD. Zdecydowano o wykonaniu badań genetycznych pod kątem zespołu Brugadów oraz wszczepieniu ILR. Chory pozostaje pod regularną kontrolą poradni zaburzeń rytmu serca.

\section{Konflikt interesów}

Autorzy deklarują brak konfliktu interesów.

\section{Abstract}

29-year-old patient was admitted to a hospital due to 2 episodes of presyncope and one syncopal episode. There were no significant abnormalities in medical history, physical examination and additional tests. Resting surface ECG showed changes suggestive of type 2 Brugada syndrome. Ajmaline challenge revealed typical ECG features of type 1 Brugada syndrome. Due to low risk of sudden cardiac death, and unclear mechanism of syncope a implantable cardioverterdefibrillator was not implanted. However the patient was provided with an implantable loop recorder in order to verify arrhythmic etiology of syncope.

Key words: Brugada syndrome, sudden cardiac death, cardioverter-defibrillator, implantable loop recorder

Folia Cardiologica 2015; 10, supl. C: $10-12$

\section{Piśmiennictwo}

1. Antzelevitch C., Brugada P., Borggrefe M. i wsp. Brugada syndrome: report of the second consensus conference: endorsed by the Heart Rhythm Society and the European Heart Rhythm Association. Circulation 2005; 111: 659-670.

2. HRS/EHRA/APHRS expert consensus statement on the diagnosis and management of patients with inherited primary arrhythmia syndromes. Heart Rhythm 2013; 10: 1932-1963.

3. Veltmann C., Schimp R., Echternach C. i wsp. A prospective study on spontaneous fluctuations between diagnostic and non-diagnostic ECGs in Brugada syndrome: implications for correct phenotyping and risk stratification. Eur. Heart J. 2006; 27: 2544-2552.
4. Brugada R., Brugada J., Antzelevitch C. i wsp. Sodium channel blockers identify risk for sudden death in patients with ST-segment elevation and right bundle branch block but structurally normal hearts. Circulation 2000; 101: 510-515.

5. Eckardt L., Probst V., Smits J.P. i wsp. Long-term prognosis of individuals with right precordial ST-segment-elevation Brugada syndrome. Circulation 2005; 111: 257-263.

6. Brugada J., Brugada R., Brugada P. Determinants of sudden cardiac death in individuals with the electrocardiographic pattern of Brugada syndrome and no previous cardiac arrest. Circulation 2003; 108: 3092-3096. 